\title{
NEW JERSEY FOURTH-OF-JULY ORATIONS, 1793-1969
}

\author{
BY DONALD A. SINCLAIR
}

Mr. Sinclair is Curator of Special Collections at Alexander Library, Rutgers.

I $\mathrm{N}$ former times the Fourth of July celebration was an exciting local event, whose highlight was a speech reviewing the nation's achievements. Many of the speeches appeared subsequently ("by request," their publishers were prone to put it) as pamphlets, and these collectively form a kind of literary category. They have similarities in style, purpose, and content, and a chronological orientation which lends itself to reflections of change. While most of them "viewed with pride," some dealt with issues of the day-politics or problems such as slavery, the Civil War, the evils of drink.

Recorded below are those Fourth of July orations, held by the Rutgers Special Collections Department, which pertain to New Jersey.* They are primarily pamphlets, although the compiler has included several which had been discovered fortuitously-no search was made for them-in periodicals or within other publications. While additional New Jersey Fourth of July orations exist, the group listed here is both substantial and representative.

A review of these ninety-five orations will show that many of their authors were local lawyers and politicians; only four doctors. Nearly a third were clergymen, usually Presbyterian. Inevitably there are seven by Episcopal bishop George Washington Doane, a dominating, vain individual who somehow managed to have scores of his minor writings and speeches committed to print.

Resident citizens' committees probably arranged a majority of the celebrations. Various organizations held or sponsored others. Conspicuous among them was the Society of the Cincinnati, and there were a few political groups-e.g., Friends of Peace (18I4), the Whigs of Newark ( I 834), and Sons of Liberty ( I86I). The ceremonies often took place in churches, Presbyterian mostly, doubtless the only buildings with seating capacity for a proper crowd.

The subject matter of the orations has been commented upon. It may be added that, while patriotic and political essays predominated,

\footnotetext{
* The Department has also many such orations from other states.
} 
there were several good local histories in the lot. These are the most enduringly useful of all, but singularly ill-suited to the needs of oratory. They were usually so long and so larded with minutiae as to have stupefied their respective audiences.

\section{3-1799}

\section{Boudinot, Elias, I 740-182I.}

"An oration, delivered at ElizabethTown (New-Jersey) agreeably to a resolution of the State Society of Cincinnati, on the $4^{\text {th }}$ of July, $1793 \ldots$ By Elias Boudinot ..." United States magazine, or, General repository of useful instruction and rational amusement. Newark, N.J. v.I, I 794, p.98-104, I $53-$ I 58 .

An oration delivered at Elizabeth Town, New Jersey, agreeably to a resolution of the State Society of the Cincinnati, on the $4^{\text {th }}$ of July, I 793 , being the seventeenth anniversary of the independence of America, by Elias Boudinot - . [Philadelphia: Press of Review printing house, I $893 \mathrm{I} \quad 24 \mathrm{P} \cdot 23 \mathrm{I} / 2 \mathrm{~cm}$.

Reprinted by the Society from the 1793 edition.

"One hundred and twenty-five copies printed ..."

MACwhorter, AleXander, I734I 807 .

A festival discourse, occasioned by the celebration of the seventeenth anninersary ${ }_{[}{ }^{s i c} c_{\text {] }}$ of American independence, in the town of Newark. By Alex. Macwhorter, D.D. To which is annexed the Declaration of Independence, which was read, with a few introductory remarks, by Alex. C. Macwhorter, esq. A.M. . . . Newark: (N.J.) Printed by John Woods, I793. 24p. $201 / 2 \mathrm{~cm}$.
Vote of thanks (p.[4]) signed: Uzal Ogden, Vice-President of the Patriotic Society.

Machhorter, Alexander Cumming, I 77 I - I 808 .

An oration delivered on the Fourth of July, I 794, to a numerous audience, assembled in the Presbyterian Church of Newark, to celebrate the eighteenth anniversary of American emancipation. By Alexander C. Macwhorter . . Newark: Printed by John Woods, 1794. 22p. I $61 / 2 \mathrm{~cm}$.

"Published at the desire of the Republican Society of the Town of Newark."

The two Rutgers copies, their half-titles and title-leaves removed, are included in volumes of left-over pamphlets, part or all of them printed also by John Woods, which he assembled in 1797 to be bound and sold together, the first in each case being $A$ Collection of Essays, on a Variety of Subjects, published in that year.

Crane, Isaac Watts, I773-1856.

An oration delivered in the Presbyterian Church, at Elizabeth-Town, on the Fourth of July, I 794, at the request of the militia officers, it being the eighteenth anniversary of American independence. By Isaac Watts Crane ... Newark: Printed by John Woods, 1795 . 23p. $161 / 2 \mathrm{~cm}$.

"Published at the request of a number of the auditors."

YarRow, Thomas, I 778 ? - I 84 I.

An oration, delivered at Port-Elizabeth, state of New-Jersey, on the Fourth of July, 1799; being the twenty-third anniversary of American independence. 
By Thomas Yarrow, M.L.C.S. . . Philadelphia: Printed by John Bioren [ 1799] 15P. 21 cm. 6

"Proceedings in Port Elizabeth ... .": p. [13]-1 5 .

1800-1809

Crane, Daniel, d. i 86 I.

An oration, delivered at Bloomfield, on the Fourth of July, I80 I. By Daniel Crane, A.B. . . . Newark, (New Jersey) Printed by Pennington \& Gould, I 801 . I6p. I $9 \mathrm{~cm}$.

"Published by request of the audience."

Contains Jeffersonian political comment.

Ogden, Lewis Morris, I 783-I 8 Io.

An oration, delivered in the Presbyterian Church at Newark, July $4^{\text {th, }}$ 1803 , being the anniversary of American independence, by Lewis Morris Ogden, A.B., student at law ... Newark: Printed by John Wallis [I803] I2P. $23 \mathrm{~cm}$.

"Published at the request of a number of the gentlemen of the town."

Dow, JoHn, I 766 ? - 1838 .

A discourse, delivered by request, July 4, I806, in the Methodist Church at Belleville. By John Dow, minister of the gospel. Newark, (N.J.) Printed by John A. Crane, I806. 22p. $21 \mathrm{~cm}$. 9

\section{[WestcotT, JAMES D.] I775-I 84I.}

An address delivered to the inhabitants of the township of Fairfield, Cumberland County, New Jersey, on the Fourth of July, I 808 ; in conformity with their previous appointment, and published in compliance with their request. Philadelphia: Printed by John Binns, I 808. I 2p. $21 \mathrm{I} / 2 \mathrm{~cm}$. 10

Copy bears contemporary manuscript note: "by James D Westcott Esq."
Boggs, John.

Orations, delivered by the Rev. John Boggs. Trenton: Printed by James J. Wilson, I 8 II. 30p. $201 / 2 \mathrm{~cm}$. 11

Delivered at Hopewell, N.J., the first for President Madison's inauguration in 1809 , the remaining three being Fourth of July orations, 1 809-I 81 I.

ImLAy, James Henderson, I 764-I 823.

Oration delivered by James $\mathrm{H}$. Imlay, in the Presbyterian Church, Allentown, on the Fourth of July, 1809 ... Trenton: Printed by James Oram, I 809 . I6p. $22 \mathrm{I} / 2 \mathrm{~cm}$.

"Published by request of the committee of arrangements."

WhelPLey, SAMUEL, I 766-I 817 .

An oration by the Rev. Samuel Whelpley ... delivered, in consequence of his illness, by his son, Melancton P. Whelpley, in the Presbyterian Church in Morris-Town, July 4, 1809 . MorrisTown: Printed by Henry P. Russell, I 809 . I $4 \mathrm{P} . \quad 23 \mathrm{I} / 2 \mathrm{~cm}$.

Copy imperfect: p.9-14 lacking.

\section{$1810-1819$}

Cook, Henry, I 769 ? - I 824 .

A discourse on American independence; delivered on the Fourth of July, I 8 I I, at Metutchen meeting-house, by the Rev. Mr. Cook. New-Brunswick: Printed and published by David \& James Fitz Randolph [I8II] I 8p. I $9 \mathrm{~cm}$.

"Agreeably to an arrangement, the Congregations of Metutchen, Samptown, Piscataway and Seventh-day Baptists met at Metutchen Meeting-House ..."

Copy imperfect: p.I 5-1 8 lacking.

"A discourse on American independence, delivered on the Fourth of July, I 8 I I, at Metuchen meeting-house, by 
the Rev. Mr. Cook." Hunt, Ezra Mundy. History of Metuchen.. Supplement. [Metuchen, I888] p.I8-24. 15

Reprinted from a copy of the original i $81 \mathrm{I}$ pamphlet in Dr. Hunt's possession.

Southard, SAmuei. Lewis, I 787-I 842.

An oration, delivered at Flemington, Hunterdon County, state of New-Jersey, on the Fourth of July, I8 I I, by Samuel L. Southard, esq. Trenton: Printed by James Oram, 18II. 2IP. $221 / 2 \mathrm{~cm}$.

Frelinghuysen, Frederick, I 788 1820 .

An oration, delivered July fourth, I 812 . Before the New-Jersey Washington Benevolent Society, in the city of New-Brunswick. By Frederick Frelinghuysen ... New-Brunswick: Published by C. D. Green \& Co.; L. Deare, printer, I8I2. I6p. $20 \mathrm{~cm}$.

Kean, Peter, 1788 ? - I 828.

An oration delivered in the Presbyterian Church at Elizabeth-Town, (N.J.) on Saturday, July 4, I8 12. By Peter Kean, esq. . . Morris-Town: Printed by Henry P. Russell, I8I2. I6p. I $9 \mathrm{~cm}$.

Clark, Daniel Atrinson, i779-1840. Independence-sermon, delivered July 4, I8I4, at Hanover, N. Jersey. By Daniel A. Clark. Newark: Printed by John Tuttle \& Co., I8I4. 24P. $2 \mathrm{I} / 2 \mathrm{~cm}$.

Stockton, Lucius Horatio, I 768 1835 .

An address delivered before the convention of the Friends of Peace of the state of New-Jersey, July 4, I 814 , by Lucius Horatio Stockton, esq., one of the delegates from Hunterdon. [Trenton? I814] 30p. $23 \mathrm{~cm}$.
Kean, Peter, I 788?-1828.

An oration, pronounced in the Presbyterian Church at Connecticut Farms, N.J., before the citizens of the township of Union, on the Fourth of July, I 8 I 8. By Peter Kean, esq. . . . ElizabethTown: Printed by J. and E. Sanderson, I 818 . I 4P. $231 / 2 \mathrm{~cm}$.

"Published at the request of the committee of arrangements."

\section{$1820-1829$}

Cumming, Hooper, I 788-1 825.

An oration, delivered at Newark, N.J,, July 4, I823. By Hooper Cumming . . pastor of the Presbyterian Church in Van De Water Street, NewYork. Newark: Printed by John Tuttle \& Co., 1823. 23p. $231 / 2 \mathrm{~cm}$.

Kean, Peter, I 788 ? - I 828 .

Oration, delivered in the First Presbyterian Church in Elizabeth-town, N.J., by the request of a committee of the honourable Cincinnati Society of New-Jersey, before his excellency the governor, the Hon. Cincinnati Society, the inhabitants of the borough of Elizabeth, and of the township of Union, July 4, I823 ... By Peter Kean, esq. ... Elizabeth-town: Printed by J. and E. Sanderson, I823. I $4 \mathrm{p}$. $24 \frac{1}{2} / 2 \mathrm{~cm}$. STRYKeR, JAMES.

An oration, delivered at Woodbridge, New-Jersey, July 4, I823. By James Stryker, esq. . . . Rahway, N.J.: Printed by James A. Bennet, I823. I6P. $20 \mathrm{~cm}$.

"Published at the Request of the Committee of Arrangements."

Henry, Symmes Cleves, i 797-I 857.

An oration delivered by appointment before the Cincinnatti ${ }_{[}$sic $_{]}$Society of 
New-Jersey, in the Presbyterian Church, Trenton, July $5^{\text {th }}$, 1824 . By Symmes C. Henry ... pastor of the Presbyterian Church in Cranbury. Trenton: Printed and published by Francis S. Wiggins, 1824. 22p. $24 \mathrm{~cm}$.

Newark, N.J. Citizens.

The first jubilee of American independence; and, tribute of gratitude to the illustrious Adams and Jefferson. Newark, N.J. Newark: Printed by $M$. Lyon and Co., 1826. 6op. incl. 3 plates. $23 \mathrm{~cm}$.

"Address" (of William S. Pennington, July 4, I 826): p.[1 I ]-I 3 .

"Address" (of William Halsey, July 4, I 826): p.[15]-32.

"Census, \&c. [of Newark] as taken by Isaac Nichols, assessor": $p \cdot[33]-36$.

"Tribute to the memory of Adams and Jefferson" (July I I, r826): p.[45J-6o. Includes (p. 552$\}-60)$ address of Philip C. Hay.

\section{$1830-1839$}

Southard, Samuel Lewis, I 787-I 842 . Address delivered before the Newark Mechanics' Association, July 5, 1830. By Samuel L. Southard . . . Newark: Printed by W. Tuttle \& Co., 1830 . 27P. $21 \frac{1}{2} \mathrm{~cm}$.

Adrain, Rober'T, I 809-I 866.

An oration, delivered on the Fourth of July, 1831. By Robert Adrain, Jr. New-Brunswick, N.J.: Printed by Van Doorn \& M'Cready, I83I. I6p. $231 / 2 \mathrm{~cm}$.

Halsted, Oliver Spencer, I792I 877 .

Address delivered before the Whigs of Newark, July $4^{\text {th }}$, 1834. By Oliver S. Halsted. Newark, N.J.: J. B. Pinneo \& Co., printers, 1834 . 34p. $23 \mathrm{~cm}$. Discusses removal from office of William J. Duane, Secretary of the Treasury.
Dayton, Aaron Ogden, i 796-i 858 .

Eulogy on La Fayette, pronounced before the Society of Cincinnati of the State of New-Jersey, on the $4^{\text {th }}$ of July, I 835. By Aaron Ogden Dayton, a member of the Society. [n.p.] 1835. 44P. $22 \mathrm{~cm}$.

Scoles, John Bentley.

An oration, delivered at Rahway, New-Jersey, July 4th, I839. By John Bentley Scoles ... New York: Applegate, printer, $1839 . \quad$ I $2 \mathrm{p} . \quad 21 \mathrm{~cm} . \quad 31$

"Published by the committee of arrangements."

\section{$1840-1849$}

\section{HaRT, John C.}

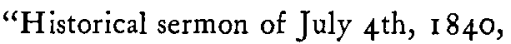
by Rev. John C. Hart, pastor, I 835I 843." Springfield, N.J. First Presbyterian Church. Commemorating the 2ooth anniversary, I745-1945... [Elizabeth, N.J., I 945 ] P.I-6.

Annotated (p.7, ro) by Rev. William Hoppaugh.

Zabriskie, James Cannon, I 804-I883.

An oration delivered on the Fourth of July, at Princeton, New Jersey. By Col. James C. Zabriskie. Princeton: Printed by John T. Robinson, I 843 . I6p. $23 \mathrm{~cm}$.

\section{Harris, Oscar.}

An address delivered in the Presbyterian Church of Basking Ridge, N.J., on the $4^{\text {th }}$ of July, I 844, by the Rev. Oscar Harris. Morristown: Hull \& Lum, printers, $1844 . \quad$ I $5 \mathrm{P} . \quad 2 \mathrm{I} / 2 \mathrm{~cm} . \quad 34$

Codpington, David S.

Oration delivered at Bergen Point, on the Fourth of July, I 845 , by David S. Coddington ... . New York: Printed 
By J. T. Crowell \& Co., I845. I4p. $14^{1} / 2 \mathrm{~cm}$.

"Published for the benefit of the Ladies" Charity Fund."

Bergen Point is now part of Bayonne.

Doane, George Washington, bp., I 799-I 859 .

Civil government a sacred trust from God: the anniversary oration before the New Jersey State Society of the Cincinnati, at Trenton, July 4, MDCCC XLV; by the Right Rev. George Washington Doane ... bishop of New Jersey. Burlington: Edmund Morris, printer, 1 $845.36 \mathrm{p} . \quad 22 \mathrm{I} / 2 \mathrm{~cm} . \quad 36$

\section{Dunbar, Joseph.}

Oration pronounced at the celebration of the Fourth of July, 1846 , at the Oaklands School, by Joseph Dunbar, a pupil of the institution: together with the other proceedings on the occasion. Burlington: Printed by Edmund Morris, I846. I4, $[\mathrm{I}]$ p. $23 \mathrm{~cm}$.

"The Oaklands School: Burlington, N.J.": p.[15] A brief prospectus.

Studiford, Peter Ogilvie, i799I 866.

The privileges and responsibilities of our country. An oration: delivered on the Fourth of July, A.D., I 846 , in the Reformed Dutch Church of Readington, by the Rev. Peter O. Studdiford ... of Lambertville, N.J. . . . New-Brunswick: Press of $\mathrm{J}$. Terhune, 1846. I7p. $22 \mathrm{r} / 2 \mathrm{~cm}$.

Doane, George Washington, bp., I 799-I 859 .

America and Great Britain: the address, at Burlington College, on the seventy-second anniversary of American independence, July 4, MDCCCXLVIII; by the Right Rev. George Washington Doane . . bishop of New Jersey, president of the college. Burlington: Edmund Morris, at the Missionary Press, 1848. I4p. $23 \mathrm{~cm}$.

The men to make a state; their making, and their marks; an address, before the trustees, teachers, and students of Burlington College; on the seventythird anniversary of American independence, and the third anniversary of the college, July 4, r849: by the Right Rev. George Washington Doane ... president of the college. Burlington: Samuel C. Atkinson, at the Missionary Press, I 849. viii, $[9]-16$ p. $22 \mathrm{~cm} .40$

\section{NAAR, DaVID, I 800-1 880.}

An oration, delivered by David Naar, in the First Presbyterian Church, Elizabethtown, New-Jersey, on the Fourth of July, I 849 , at the request of the committee. Elizabethtown, N.J.: James S. and Albert D. Drake, printers, Essex Standard office, I 849 . I $8 \mathrm{p} . \quad 22 \mathrm{r} / 2 \mathrm{~cm}$.

\section{0-1859}

Miller, Jacob Welsh, I 800-1862.

Oration; pronounced by the Honorable J. W. Miller, of the U.S. Senate, on the Fourth of July, 1851, at Morristown, New Jersey . . . Newark, N.J.: Printed at the office of the Newark Daily Advertiser, I $85 \mathrm{I}$. 20p. 22 $\mathrm{I} / 2$ $\mathrm{cm}$.

"Published by request of the Committee."

Patriotic sentiment in the early fifties: a reminiscence of the celebration of Independence Day at Newark, N.J., 
July 4th, I 851 . Oration by Amzi Dodd, esq. [Newark? I 90-?] 24 p. $23 \mathrm{~cm}$.

"The oration": p.ro-24.

Stockton, Robert Field, I795-1866. Address of Hon. R. F. Stockton, delivered at Elizabethtown, New Jersey, July $4^{\text {th, }}$ I 85 I. Trenton, N.J.: Printed at the "True American" office, I $85 \mathrm{I}$. I6p. $22 \mathrm{~cm}$.

Deals considerably with contemporary politics.

Doane, George Washington, bp., I 799-I 859 .

Influence, without intervention; the duty of our nation to the world: the oration, at Burlington College, on the seventy-sixth anniversary of American independence, and sixth, of the founding of the college, July 5, MDCCC LII: by the Rt. Rev. George Washington Doane ... bishop of the Diocese, president of the college. Burlington: Printed by John Rodgers, 1852. 17p. $22 \mathrm{~cm}$.

[McDowell, Augustus William $]$ d. I 878 .

"Fourth of July oration at Pluckamin." Our home. Somerville, N.J. v.I, I 873, P.3 14-3 I 8 .

Delivered "shortly after the Presbyterian Church was built" (i.e., I 852 ?), according to the introductory note signed "A.W.M."

\section{Shannon, Isaac N., I 82 I-I 858 .}

Divine providence in American history and politics. A discourse delivered in the Second Presbyterian Church, New-Brunswick, N.J., July 4, I852. By Rev. Isaac N. Shannon, pastor of said church . . . New-Brunswick: A. Ackerman, publisher, $1852.24 \mathrm{p} .23 \mathrm{~cm}$.
Doane, George Washington, bp., I 799 -I 859 .

The young American; his dangers, his duties, \& his destinies: the address, at Burlington College, July 4, I 853 , the serenty-seventh anniversary of American independence, and the seventh anniversary of the founding of Burlington College: by the Rt. Rev. George Washington Doane ... president. Philadelphia: Inquirer press, I853. 17p. $22 \mathrm{~cm}$.

Rrder, Anthony H., I 824?-I898?

An oration, pronounced at Bergen

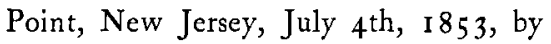
A. H. Ryder. New York: Printed by E. O. Jenkins, 1853. I 5 P. $231 / 2$ $\mathrm{cm}$.

Bergen Point is now part of Bayonne.

Doane, George Washington, bp., I799-I 859 .

E pluribus, unum: the address, at Burlington College; on the seventyeighth anniversary of American independence, and eighth anniversary of the institution; July 4, I 854: by the Right Reverend George W. Doane . . bishop of New Jersey, president of the college. Burlington: Printed at the Gazette office, I 854. 20p. $22 \mathrm{~T} / 2 \mathrm{~cm}$. 50

Organizations, dangerous to free institutions: the address, at Burlington College, July 4, I855; the seventyninth anniversary of American independence, and the ninth anniversary of the founding of Burlington College: by the Rt. Rev. George Washington Doane . . . president. Philadelphia: Inquirer book press, 1855 . $16 \mathrm{p} . \quad 221 / 2 \mathrm{~cm}$. 
Lytle, Thomas G., d. 1879.

Address delivered before the Young Men's Literary Association, at the occasion of their annual exercises on the Fourth of July, at Mercer Hall, Princeton, N.J., July 5th, 1858 , by Thomas G. Lytle, esq. . . . [ ${ }_{\text {Princeton }}$ Printed at the Princeton Press office, 1858. 22p. $21 \mathrm{~cm}$.

"Published by resolution of the Association."

Busteed, Richard, i 822-I898.

Oration delivered at Morristown, New Jersey, July 4th, 1859 . By Richard Busteed. New York: Chas. W. Baker, printer, $1859.16 \mathrm{p} .21 \mathrm{~cm}$.

\section{Hall, John, I 806-I 894 .}

The examples of the Revolution. The anniversary oration of the Cincinnati of New Jersey, at Trenton, July 4, 1859. By John Hall, D.D. Trenton, N.J.: Murphy \& Bechtel, printers, 1859. 28p. $22^{1} / 2 \mathrm{~cm}$.

\section{Morristown, N.J. Citizens.}

Proceedings at the celebration of the eighty-third anniversary of American independence, July $4^{\text {th }}, 1859$, on Wattnong Plains, Morristown, N.J. ... New York: Wm. C. Bryant \& Co., printers, I 859. I $2 \mathrm{p} . \quad 23 \frac{1}{2} \mathrm{~cm}$.

"Printed for private circulation."

"Oration": p.[5]-I 2. By Charles A. Davison.

\section{$1860-1869$}

\section{Parker, Cortlandt, i 8 i 8-ig07.}

The present contest—our rightfulness in waging it—its necessity-our duty. An oration delivered at Newark, N.J., July 4, I86I, by Cortlandt Parker, esq. [Newark, I86I] 8p. $23 \mathrm{~cm}$. 56 Caption title.

\section{Princeton, N.J. Citizens.}

Celebration of the Fourth of July, I 86I, in Princeton, N.J. Princeton, N.J.: J. T. Robinson, printer, I86I. 24P. $22 \mathrm{I} / 2 \mathrm{~cm}$.

"The Constitution not a compact between sovereign states": p.[5]-24. Oration by Richard S. Field.

\section{VANATTA, JACOB, I 824-I 879 .}

Oration delivered by Jacob Vanatta, esq., before the Society of the Sons of Liberty, of the city of Rahway, N.J., at the celebration of the anniversary of American independence, July 4, I86I .. Jersey City: John H. Lyon \& Co., steam printers, I $86 \mathrm{I}$. 20p. $23 \mathrm{~cm}$.

"Published by the Society."

\section{Hunt, Ezra Mundy, I 830-I 894.}

The war and its lessons, by Ezra M. Hunt . . New York: Printed by F. Somers, 1862. 35p. $22 \mathrm{~cm}$. 59

Possibly a July $4^{\text {th }}$ oration, Hunt was a Metuchen physician.

Parker, Cortlandt, 1818 -i 907.

The moral guilt of the Rebellion. An oration delivered at Newton, N.J., July 4, I 862, by Cortlandt Parker, esq. [Newton? I 862] $12 \mathrm{p} . \quad 22 \mathrm{~cm} .60$ Caption title.

\section{Pugh, John Howard, I 827-1905.}

Our Union and its defenders: an oration, delivered before the citizens of Burlington, N.J., on the occasion of their celebration of the eighty-sixth anniversary of Independence Day, July

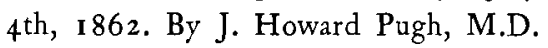
Philadelphia: King \& Baird, printers, I 862. 23p. $2 \mathrm{I} / 2 \mathrm{~cm}$.

Dunn, Lewis Romaine, i 82 2-I 898.

An oration delivered at Morristown, N.J., July $4^{\text {th }}$, 1863 , by Rev. L. R. 
Dunn, pastor of the M. E. Church . . . Morristown, N.J.: A. A. Vance, printer, I 863. 23p. $23 \mathrm{~cm}$.

"Published by request."

Alexander, Stephen, I 806-I 883 .

Address delivered on the eighty-ninth anniversary of our national independence, at Princeton, N.J., by Prof. Stephen Alexander . . . Princeton: Printed at the Standard book and job office, I $865 . \quad 25,\left[I_{]}\right.$p. $\quad 22 \mathrm{~cm}$.

Parker, Cortlandt, i 8i 8-i 907.

Our triumph and our new duties. Oration delivered by Cortlandt Parker, esq., at Bloomfield, N.J., July 4, I 865. Newark, N.J.: A. Stephen Holbrook, printer, I $865.38 \mathrm{p} . \quad 24 \mathrm{~cm}$.

PARKer, JokL, I 816-I 888 .

Oration delivered by Governor Parker, at the dedication of a monument to the memory of John Hart, one of the signers of the Declaration of Independence from New Jersey, at Hopewell, Mercer County, New Jersey, July 4th, I 865. Trenton, N.J.: Printed at the "True American" office, I 865. 28, [ I $]$ P. $22 \frac{1}{2} \mathrm{~cm}$.

"The Stout family": p.26-28.

Oration delivered by Governor Parker at the dedication of a monument to the memory of John Hart, one of the signers of the Declaration of Independence from New Jersey, at Hopewell, Mercer County, N.J., July $4^{\text {th, }}$ I 865 . Hopewell, N.J.: C. E. Voorhees, newspaper, book and job printer, I 896 . 26p. port. $22 \mathrm{I} / 2 \mathrm{~cm}$.

66

"The Stout family": p.24-25.

Pugh, John Howard, I 827-1905.

The success and promise of the
American union, an oration, delivered before the citizens of Burlington, N.J., on the occasion of their celebration of the eighty-ninth anniversary of Independence Day, July 4th, I 865 . By J. Howard Pugh, M.D. Philadelphia: King \& Baird, printers, I 865. 24P. $23 \mathrm{~cm}$.

"The jubilee of freedom. By John Collins": p.23-24. Poetry.

Shaw, Charles Dannelly, i 834-I 909.

An oration delivered at the Wigwam, Paterson, N.J., on July 4th, I 865 , by Rev. Chas. D. Shaw, with a "roll of honor," comprising the names of Paterson soldiers, who have given their lives to their country. Paterson, N.J.: Printed by Chiswell \& Wurts, "Press" office, I 865. 24p. $22 \mathrm{~cm}$.

Electrostatic copy.

Kelley, William Valentine, i 8431927.

"American nationality, and its genius." Oration delivered by Rev. Wm. V. Kelley . . of the New Jersey M.E. Conference, before the Alpha-Omega Society, of Pennington Seminary, July $4^{\text {th }}$, I $867 \ldots$ Trenton, N.J.: Printed at the office of the State Gazette, I 867. I $7 \mathrm{p}$. $2 \mathrm{I} / 2 \mathrm{~cm}$.

Newark, N.J. Citizens.

Programme of the celebration of the ninety-second anniversary of American independence, at Newark, N.J., July $4^{\text {th, }}$ 1868, together with the address of Hon. Lyman Tremain, of New York. Newark, N.J.: Evening Courier print, I 868. I 8p. $22 \mathrm{~cm}$. 70

Stockton, John Potter, 1826-1900. Address of Hon. John P. Stockton, of New Jersey, before the Tammany 
Society, of New York, July 5, 1869. Trenton, N.J.: Printed at the True American office, 1869. 22p. $22 \mathrm{r} / 2 \mathrm{~cm}$. 13-22.

"Fifteenth Constitutional Amendment": p.

\section{$1870-1879$}

\section{Green, Edward T.}

Oration delivered before the East Windsor Soldiers' Monument Association, at Hightstown, N.J., July $5^{\text {th, }}$ I 875, by Edward T. Green ... Trenton, N.J.: Murphy \& Bechtel, steam power book and job printers, I 875 . I $4 \mathrm{p}$. $22 \mathrm{I} / 2 \mathrm{~cm}$.

"Printed by request."

\section{Moses, Richard G.}

Free institutions and Bible principles of society, a sermon preached in Camden, N.J., July 4, I 875 , by R. G. Moses, pastor of the North Baptist Church, Camden . . Philadelphia, 1875. cover-title, 8p. illus. (on cover) $20 \mathrm{~cm}$.

Letterpress on covers includes historical sketch of the church.

"Price, ro cents. Proceeds in aid of the centennial mortgage fund of the North Baptist Church."

Dilts, Isaiah Neighbour, i $824-1878$.

Address by I. N. Dilts, esq., a member of the Somerville bar. [Somerville, N.J.: Somerset Gazette printing house, 1876] I 2p. $22 \mathrm{~cm}$.

Cover-title: 1776. Address on the Fourth of July, by I. N. Dilts. 1876 .

Evidently delivered in Somerville.

\section{Harris, Frederick Halsey, i $830-$}

An historical sketch of Montclair. From its earliest settlement to the centennial anniversary of national independence. Compiled by Gen. F. H. Harris, and read at the centennial

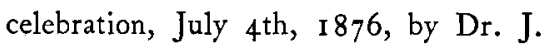
J. H. Love. Montclair, N.J.: Montclair Times steam print, I881. 26p. illus. (incl. port.) $24 \mathrm{~cm}$.

"The Exordium and peroration, as well as the portions of the sketch relating to the war records and schools, were prepared by Dr. J. J. H. Love."-p.6.

Hickok, Henry Franklin, I 832-I 90 I. ... A sermon, by the Rev. Henry F. Hickok, preached on Sunday, July 2, I876, at the Second Presbyterian Church, of Orange, N.J. . . Orange, N.J.: Printed at the Orange Chronicle book and job printing office, 1876 . I 4P. $22 \mathrm{~T} / 2 \mathrm{~cm}$.

At head of title: 1776.1876 .

Caption title: Centennial sermon.

Hill, Thomas Wilton, I 835-I89I.

Jamesburg, New Jersey. Historical address, by T. Wilton Hill, July 4th, 1876. Philadelphia: Allen, Lane \& Scott's printing house, 1876. 28p. $231 / 2 \mathrm{~cm}$.

"Historical address. Delivered at Wigwam Grove, Jamesburg, New Jersey, July $4^{\text {th }}$, 1876 , by T. Wilton Hill, cashier, First National Bank, Jamesburg, New Jersey." Centennial and historical exercises at Jamesburg, N.J., ${ }_{1} 876$. Phila., I 876. p.53-76.

\section{Jersey City, N.J. Citizens.}

The celebration of the centennial of American independence, by the inhabitants of Communipaw and Lafayette, on the Fourth of July, 1876, in the Reformed Church . . L Lafavette, Jersey City. New York: John Mcllroy, steam book and job printer $\left[1876_{1}\right.$ 22p. $23 \mathrm{I} / 2 \mathrm{~cm}$. 
"Historical sketch of Communipaw and Lafayette": p.8-12. By Rev. William R. Duryee.

"Oration": p.I3-I8. By J. T. Van Cleef, Esq.

\section{[SPRingfield, N.J.]}

Springfield, Union County, N.J. The history of its centennial Fourth, committees, meetings, procession, and oration by Rev. H. W. Teller. Exhibitions, press remarks and historical items. Newark, N.J.: Printed by Ward \& Tichenor, 1876. 36p. illus. (incl. map) $22 \frac{1}{2} \mathrm{~cm}$.

Tuttle, Joseph Farrand, i 8I 8-igoi. ... The Revolutionary forefathers of Morris County, an address delivered at Morristown, N.J., July 4th, I 876 , by Rev. Joseph F. Tuttle ... Dover, N.J.: Benj. H. Vogt, printer-The Iron Era office, 1876 . cover-title, $8 \mathrm{p} . \quad 22 \mathrm{2} / 2 \mathrm{~cm}$. At head of title: 1776 . Centennial. 1876 .

"The Revolutionary forefathers of Morris County." [Tuttle, Joseph Farrand $_{3}$ Centennial collections of Morris County. [Morristown? I 877?] p.86-93.

"An oration delivered at Morristown, July 4th, 1876."

WeST, JOSEPH HARRISON, I 847-I9I6.

A history of the village of Hamilton Square, Mercer County, New Jersey; being also a history of the section now included in Mercer and Burlington counties; names of first settlers and acres owned; Nottingham Township; churches and burying grounds, with an introductory sketch of the first settlement of New Jersey. Written to be read on the occasion of the celebration at Hamilton Square, on July 4th, 1876 , by Joseph $\mathrm{H}$. West. Containing also the speeches of Dr. G. R. Robbins and Rev. W. W. Case, delivered at the celebration, with an account of the proceedings of the day ... Trenton, N.J.: John L. Murphy, State Gazette printing house, I $876 . \quad 42 \mathrm{p} . \quad 22 \mathrm{I} / 2 \mathrm{~cm}$.

Copy contains manuscript annotations by the author.

\section{$1880-1889$}

Baily, Joshua Longstreth, I826I9I6.

Slavery of the drink system. A Fourth of July oration. Delivered at Camden, N.J., July 5th, I 886 , by Joshua L. Baily. Camden, N.J.: Temperance Gazette printing house, I $886.31 \mathrm{p}$. I $9 \mathrm{~cm}$.

84

\section{0-1899}

Halsey, Luther Foster, I 833-I 895.

The Revolutionary worthies of the medical staff, by Luther Foster Halsey, M.D. . . . [Philadelphia: Review printing house, I89I] $84,\left[I^{I} \mathrm{P}\right.$. table. $23 \mathrm{I} / 2 \mathrm{~cm}$.

"Read before The Society of The Cincinnati in the State of New Jersey, at Princeton, July 4, I 890."

Includes lists of medical officers and (p.2944) military service records, etc., of New Jersey physicians.

Cook, J. Hervey.

An oration delivered in the Presbyterian Church at Succasunna, N.J., July 4, I 893, by J. Hervey Cook, of Fishkillon-the-Hudson, N.Y. . . . [Fishkill, N.Y.? I893] 15 p. $\quad 23 \mathrm{~cm}$. 86

Gray, Nomer, ed.

Hopewell's celebration of the 120 th anniversary of the Declaration of Independence. The unveiling of the Hough- 
ton memorial. By Nomer Gray, Ph.B. Hopewell, N.J.: C. E. Voorhees, newspaper, book and job printer, 1896. I p.1.,[5]-25P. port. $2 \mathrm{I} 1 / 2 \mathrm{~cm}$. 87 Letterpress on covers.

Includes addresses by Ralph Ege, Jacob Weart, and George Lansing Raymond.

Pennington, William, i 866-r 922.

"The beginnings of the Society of the Cincinnati. By William Pennington. Read before the Society of the Cincinnati in the State of New Jersey on July 5th, I 897." Society of the Cincinnati. New Jersey. Historical papers . . 1897 . Brooklyn [ 1897 ] P.[27]-37.

\section{From 1900}

Dayton, Hughes, I 873-1944.

"... Elias Dayton, brigadier general, Continental Line of New Jersey." Society of the Cincinnati. New Jersey. Historical papers ... r gor. Brooklyn [ I 1901 ] P.I I 7 ] -3 I.

"Read before the Society of the Cincinnati in the State of New Jersey, at Atlantic City, N.J., July 4th, 1901. By Hughes Dayton, A.M., M.D., New York."

WherRy, JAMES.

". . Santiago-de-Cuba, I 898." Ibid., p. $[5]^{-1} 6$.

"Read before the Society of the Cincinnati in the State of New Jersey, at Atlantic City, N.J., July 4th, 190I, by Brig. Gen. James Wherry, U.S.A.—retired."

\section{Bergen, Frank, I 85 1-1934.}

"Speech dedicating soldiers' monument." Essays and speeches of Frank Bergen. Newark, 1931. v.2, p. $566_{-}-58$.

"Delivered at dedication of Soldiers' and Sailors' Monument at Elizabeth, New Jersey. July 4, I 906."
Pennington, William, i 866-i 922.

An awakening. Address delivered at Allenhurst, New Jersey, July 4, I 9 I I, upon the occasion of the annual meeting of the Society of the Cincinnati in the State of New Jersey, by the Hon. William Pennington, vice-president of the Society. [n.p., I9II] $7 \mathrm{p}$. $24 \% / 2 \mathrm{~cm}$.

Halford, Elijah Walker, I 843-

"The nation: what it is-what it costs. Address by Lieut. Col. E. W. Halford, Leonia, N.J., July 4, I9I6 ..."Bergen County Historical Society. ${ }_{\text {[}}$ Papers and proceedings] ("Eighteenth annual report") no. 13, I 920, p. 34-42.

"Unveiling of Washington commemorative tablet-passage of Revolutionary troops from Fort Lee through Leonia to Hackensack and Trenton."

\section{Ward, William Rankin, I870-}

Our heritage. An address delivered at the celebration of the sesquicentennial of American independence, Weequahic Park, Newark, New Jersey, Monday, July 5, 1926. ${ }_{[} \mathrm{By}_{]}$William Rankin Ward, president of the New Jersey Society, Sons of the American Revolution. Newark, N.J., 1926. 14p. $23 \mathrm{~cm}$.

94

[Cunningham, John Thomas] igi6-

Master of strategy: Washington turned the tide in Somerset to victory in the Revolution. [Somerville, N.J.: Published by the Somerset MessengerGazette, 1969] 8p. (incl. port.) $26 \mathrm{~cm}$.

An Address delivered July 4, 1969, at the Wallace house, Somerville, under the auspices of the Revolutionary Memorial Society of New Jersey. 


\section{N D E X}

Adams, John, 26

Adrain, Robert, 28

Alexander, Stephen, 63

Allenhurst, 92

Allentown, I 2

Alpha-Omega Society, Pennington Seminary, 69

Atlantic City, 89, 90

Baily, Joshua Longstreth, 84

Baptist churches: Camden (North Church), 73

Basking Ridge, 34

Bayonne, see Bergen Point

Belleville, 9

Bergen, Frank, 9 I

Bergen County localities, see Leonia

Bergen Point, 35, 49

Bloomfield, 7,64

Boggs, John, I I

Boudinot, Elias, I, 2

Burlington, 37, 39, 40,45, 48,50, 51, 61, 67

Burlington College, 39, 40, 45, 48, 50, $5 \mathrm{I}$

Busteed, Richard, 53

Camden, 73, 84

Case, William W., 83

Civil War, 56-64, 67, 68, 70-72

Clark, Daniel Atkinson, 19

Coddington, David S., 35

A Collection of Essays, 4

Collins, John, 67

Communipaw, Jersey City, 79

Connecticut Farms, see Union

Constitution (U.S.), 57; I 5 th Amendment, 71

Cook, Henry, 14, 15

J. Hervey, 86

Crane, Daniel, 7

Isaac Watts, 5

Cumberland County localities, see Fairfield Township; Port Elizabeth

Cumming, Hooper, 22

Cunningham, John Thomas, 95

Davison, Charles A., 55

Dayton, Aaron Ogden, 30

Elias, 89

Hughes, 89

Declaration of Independence, 3

Democratic Party, 7; Newark, 4

Dilts, Isaiah Neighbour, 74

Doane, George Washington, 36, 39, 40, 45, $48,50,5 \mathrm{I}$
Dodd, Amzi, 43

Dow, John, 9

Duane, William J., 29

Dunbar, Joseph, 37

Dunn, Lewis Romaine, 62

Duryee, William R., 79

East Windsor Soldiers' Monument Association, 72

Ege, Ralph, 87

Elizabeth, 1, 2, 5, I 8, 23, 4I, 44, 91

Essex County localities, see Belleville; Bloomfield; Montclair; Newark; Orange

Fairfield Township, Io

Field, Richard S., 57

Flemington, $x 6$

Frelinghuysen, Frederick, I 7

Friends of Peace, 20

Gray, Nomer, 87

Green, Edward T., 72

Halford, Elijah Walker, 93

Hall, John, 54

Halsey, Luther Foster, 85

William, 26

Halsted, Oliver Spencer, 29

Hamition Square, 83

Hamilton (formerly Nottingham) Township, 83

Hanover, I 9

Harris, Frederick Halsey, 75

Oscar, 34

Hart, John, 65, 66

John C., 32

Hay, Philip C., 26

Henry, Symmes Cleves, 25

Hickok, Henry Franklin, 76

Hightstown, 72

Hill, Thomas Wilton, 77,78

Hopewell, 11 , 65, 66, 87

Hoppaugh, William, 32

Houghton memorial, Hopewell, 87

Hudson County localities, see Bergen Point; Jersey City

Hunt, Ezra Mundy, 59

Hunterdon County localities, see Flemington; Readington

Imlay, James Henderson, I 2

Jamesburg, 77,78 
Jefferson, Thomas, 26

Jersey City, 79

Kean, Peter, 18, 21, 23

Kelley, William Valentine, 69

Ladies' Charity Fund, Bergen Point, 35

Lafayette, Marquis de, 30

Lafayette, Jersey City, 79

Leonia, 93

Liquor problem, 84

Love, J. J. H., 75

Lytle, Thomas G., 52

McDowell, Augustus William, 46

Macwhorter, Alexander, 3

Alexander Cumming, 3, 4

Mercer County localities, see Hamilton Square; Hamilton Township; Hightstown; Hopewell; Princeton

Methodist churches: Belleville, 9

Metuchen, 14, 15, 59

Middlesex County localities, see Jamesburg; Metuchen; New Brunswick; Woodbridge

Militia, 5

Miller, Jacob Welsh, 42

Monmouth County localities, see Allenhurst; Allentown

Montclair, 75

Morris County, 81,82

localities, see Hanover; Morristown; Succasunna

Morristown, I 3, 42, 53, 55, 62, 8I, 82

Moses, Richard G., 73

Naar, David, 4I

New Brunswick, 17, 28, 47

New Jersey, Washington Benevolent Society of, 17

New York City, 7 I

Newark, 3, 4, 8, 22, 26, 27, 29, 43, 56, 7o, 94

Newark Mechanics' Association, 27

Newton, 6o

Nichols, Isaac, 26

Nottingham Township, see Hamilton Township

Oaklands School, Burlington, 37

Ogden, Lewis Morris, 8

Uzal, 3

Orange, 76

Parker, Cortlandt, 56, 60, 64

Joel, 65,66

Paterson, 68
Patriotic sentiment in the early fifties, 43

Patriotic Society, Newark, 3

Pennington, William, 88, 92

William S., 26

Pennington, 69

Physicians, 85

Pluckamin, 46

Port Elizabeth, 6

Presbyterian churches

Allentown, I 2

Basking Ridge, 34

East Orange (Second Presbyterian Church of Orange), 76

Elizabeth (First), 5, 18, 23, 4I

Metuchen, I 4, I5

Morristown, I 3

New Brunswick (Second), 47

Newark (First), 4, 8

Pluckamin, 46

Spring field (First), 32

Succasunna, 86

Trenton, 25

Union (Connecticut Farms), 2I

Princeton, 33, 52, 57, 63, 85

Pugh, John Howard, 6I, 67

Rahway, 31, 58

Raymond, George Lansing, 87

Readington, 38

Reformed churches

Lafayette (Jersey City), 79

Readington, 38

Republican Society of the Town of Newark, 4

Revolutionary Memorial Society of New Jersey, 95

Robbins, George R., 83

Ryder, Anthony H., 49

Santiago-de-Cuba, 90

Scoles, John Bentley, 3 I

Shannon, Isaac N., 47

Shaw, Charles Dannelly, 68

Society of the Cincinnati, I, 2, 23, 25, 30, 36, $54,85,88,89,90,92$.

Soldiers' and Sailors' Monument, Elizabeth, 9 I

Somerset County localities, see Basking

Ridge; Pluckamin; Somerville

Somerville, 74, 95

Sons of Liberty, Rahway, $5^{8}$

Southard, Samuel Lewis, I6, 27

Springfield, 32, 80

Stockton, John Potter, 7I

Lucius Horatio, 20

Robert Field, 44 
Stout family, 65,66

Stryker, James, 24

Studdiford, Peter Ogilvie, 38

Succasunna, 86

Sussex County localities, see Newton

Tammany Society, New York, 7 I

Teller, Henry W., 8o

Tremain, Lyman, 70

Trenton, 25, 36, 54

Tuttle, Joseph Farrand, 81, 82

Union (Connecticut Farms), 2 I

Union County localities, see Elizabeth; Rahway; Springfield; Union; Union Township

Union Township, 21, 23

Vanatta, Jacob, 58

Van Cleef, John T., 79
Wallace house, Somerville, 95

Ward, William Rankin, 94

Washington Benevolent Society of New Jersey, I 7

Weart, Jacob, 87

Weequahic Park, Newark, 94

West, Joseph Harrison, 83

Westcott, James D., ro

Whelpley, Melancton P., I 3

Samuel, 13

Wherry, James, 9o

Whig Party, Newark, 29

Woodbridge, 24

Yarrow, Thomas, 6

Young Men's Literary Association, Princeton, 52

Zabriskie, James Cannon, 33 